ISSN 0258-7122 (Print), 2408-8293 (Online)

Bangladesh J. Agril. Res. 42(2): 301-307, June 2017

\title{
OPTIMUM SAMPLING PLAN OF YIELD CONTRIBUTING CHARACTERS OF POINTED GOURD
}

\author{
N. MOHAMMAD ${ }^{1}$, M. S. ISLAM ${ }^{2}$, K. S. RAHMAN ${ }^{3}$ \\ M. M. RAHMAN ${ }^{4}$ AND M. M. RAHMAN ${ }^{5}$
}

\begin{abstract}
To improve efficiency in collecting data from field experiment on fruit attributes of pointed gourd (Patal) the sample size was studied for determining optimum sample size at Olericulture Division, Horticulture Research Centre (HRC) of Bangladesh Agricultural Research Institute (BARI) Gazipur during 2013-14. Fruit length, breadth and weight data were used to design optimum sampling plan for equal number of observations per cell. The observation on fruit length $(\mathrm{cm})$, breadth $(\mathrm{cm})$ and weight $(\mathrm{gm})$ were taken from 7 plots/treatments at random. A randomized complete block design (RCBD) with 2 replications and seven treatments/varieties were used in this experiment. A sampling plan of selecting 3 plants at random and measuring 9 fruits per selected plant ( 27 fruits per plot and plots were $5 \mathrm{~m}^{2}$ i.e. $2.5 \mathrm{~m}$ long and $2 \mathrm{~m}$ wide) was found to be optimum and economy for the measurement of fruit attributes of pointed gourd. It saves time required for constant vigilance opening of flower and subsequent observations.
\end{abstract}

Keywords: Optimum sample size, Sampling technique, Relative efficiency, Variance component and Pointed gourd.

\section{Introduction}

Pointed gourd (Trichosanthes dioica) locally known as 'patal' is a common vegetable and its yield depends on various characteristics like fruit length, breadth, weight etc. Determination of optimum sample size is a major issue and challenge in any field experiment. According to Islam et al. (2000), it is necessary to determine the optimum samples as well as optimum number of replications for collecting data under any sampling plan in a field experiment. In any field experiments, it is necessary to determine the optimum sample size as well as optimum number of replications if researchers have to use sampling techniques for collecting data from such experiments (Islam et al., 2000). Frequently, it is not possible to measure yield and yield contributing characteristics on the whole of each experimental unit. In any field experiment, the researcher has to face the problem in determining optimum (efficient) sample size for measuring plant characters (Federer, 1963) and (Islam, 2001). The optimum sampling technique depends on the variability associated with variable and the cost of reducing the variability (Kempthorne ,1952). Rigney and Nelson

${ }^{1,3 \& 4}$ Scientific Officer, ASICT Division, Bangladesh Agricultural Research Institute (BARI), Gazipur-1701, ${ }^{2}$ Principal Scientific Officer, ASICT Division, BARI, Gazipur1701, ${ }^{5}$ Scientific officer, Pulse Research Sub Center, BARI, Gazipur-1701, Bangladesh. 
(1951) in cotton, Patel and Dalal (1992) in okra and Hossain et al. (2005) in Brinjal, Hossain et al. (2008) in Teasle gourd, Islam et al. (2012) in Sweet gourd , Islam et al. (2013) in Bitter gourd and Mohammad et al. (2015) in Bottle gourd estimated sample sizes on their respective plant characters. No such information is available for patal. As such the researchers are intended to conduct a field experiment deals with sample size study in pointed gourd particularly for taking measurements of fruit character like length, breadth and weight of patal. The investigation was carried out at Horticulture Research center (HRC), Bangladesh Agricultural Research Institute (BARI), Joydebpur, Gazipur in 20132014. The objective of the study is to find out optimum sample size for estimating yield contributing characters of patal through proper field experiment.

\section{Material and Method}

Estimation of sample sizes depend on number of variables, replications and cost involvement in an experiment. Because an experimenter is always intended to reduce the cost and time of the experiment. Thus, it is necessary to choose optimum sample size and number of replications in a good experiment. Estimation of optimum sample size and number of replications are obtained by maximizing the information for a given cost.

The experiment was conducted at Horticulture Research Center (HRC), Bangladesh Agricultural Research Institute (BARI), Joydebpur, Gazipur in 20132014. There were seven treatments/varieties used as treatment in this experiment. The treatments/varieties were PG014xM1, PG008xM2, PG009xM2, BARI Patal2, PG018xM2, PG027xM2 and BARI Patal-1. Experimental plot was $5 \mathrm{~m}^{2}(2.5 \mathrm{~m}$ long and $2 \mathrm{~m}$ wide) and spacing was $(1.5 \times 1.0) \mathrm{m}$. Fruit length, breadth and weight of pointed gourd (Patal) data were collected from the experimental plot. This data were used to calculate optimum sampling plan from equal observation per cell. The observation on fruit length $(\mathrm{cm})$, breadth $(\mathrm{cm})$ and weight $(\mathrm{gm})$ were taken from 7 plots or treatments selected at random. The fruit length, breadth and weight of ten fruits from each selected plant utilized in this analysis. There were 30 fruits ( 3 plants per plot x 10 fruits per plant) per plot and 210 fruits per replication. Considering the time factor, the data of two replications were collected for deriving optimum sampling plan (Optimum in the sense of time involved in taking fruits measurements). A randomized complete block design (RCBD) with 2 replications was used for this experiment. The data were analyzed replication wise by two-way analysis of variance (ANOVA) technique (Table 1) to estimate variance components associate with plots $\left(\hat{\sigma}_{p}^{2}\right)$, plants $\left(\hat{\sigma}_{q}^{2}\right)$ and fruits $\left(\hat{\sigma}_{n}^{2}\right)$.

\section{Analytical Model}

According to the objective of the study of a field experiment should be conducted using a proper statistical model. In this experiment $p$ treatments (plots) are taken 
at random, then q plants are selected randomly from each treatment of $\mathrm{n}$ sampling unit.

Therefore, the statistical model is as

$$
Y_{i j k}=m+a_{i}+\beta_{i j}+\eta_{i j k}
$$

where, $i=1,2 \ldots \ldots \ldots . p, j=1,2, \ldots \ldots, q$ and $k=1,2, \ldots ., n$

where

$m=$ the general mean

$\alpha_{\mathrm{i}}=$ the treatments effect

$\beta_{i j}=$ the plants effect due to the (ij)th experimental unit.

$\eta_{i j k}=$ the sampling effect due to the (ijk)th observation

For the study we suppose that the $\eta_{i j k}$ 's are normally and independently distributed with variance $\sigma_{n}^{2}, \beta_{i j}$ 's are normally and independently distributed with variance $\sigma_{q}^{2}$ and $\alpha_{i}$ 's are normally and independently distributed. The $\eta_{i j k}$ 's will be independent of the $\beta_{i j}$ 's and $\alpha_{i}$ 's if the sampling random.

The least square estimates are obtained as follows:

$\hat{m}=\bar{y} \ldots$

$\hat{a}_{i}=\left(\bar{y}_{i \ldots}-\bar{y}_{\ldots}\right.$

$\hat{\beta}_{i j}=\left(\bar{y}_{i j .}-\bar{y}_{i . .}\right.$

$\hat{\pi}_{i j k}=\left(\bar{y}_{i j k}-\bar{y}_{i j}\right.$.

Also

$\bar{y}_{\ldots .}=\frac{\sum_{j=1}^{p} \sum_{j=1}^{q} \sum_{k=1}^{n} y_{i j k}}{p q n} \bar{y}_{i \ldots .}=\frac{\sum_{j=1}^{q} \sum_{k=1}^{n} y_{i j k}}{p n} \bar{y}_{i j \ldots}=\frac{\sum_{k=1}^{n} y_{i j k}}{n}$

Putting these values in equation (l) and squaring and summing on both sides. Then the total sum of squares can be partitioned as:

$\sum_{i=1}^{p} \sum_{j=1}^{q} \sum_{k=1}^{n}\left(y_{i j k}-\bar{y}_{\ldots}\right)^{2}=n q \sum_{i=1}^{p}\left(\bar{y}_{i . . .}-\bar{y}_{\ldots . .}\right)^{2}=n \sum_{i=1}^{p} \sum_{j=1}^{q}\left(\bar{y}_{i j}-\bar{y}_{i . . .}\right)^{2}+\sum_{i=1}^{p} \sum_{j=1}^{q} \sum_{k=1}^{n}\left(y_{i j n}-\bar{y}_{i j . .}\right)^{2}+$ producttern

But product terms are usually zero.

Thus, Total $($ SS $)=$ Treatment $($ SS $)+$ Plant $($ SS $)+$ Sampling $($ SS $)$

With their degrees of freedom $(n p q-1)=(p-1)+p(q-1)+p q(n-1)$ 
Table 1. The analysis of variance

\begin{tabular}{|l|c|c|c|l|}
\hline \multicolumn{1}{|c|}{$\begin{array}{c}\text { Sources of } \\
\text { Variation (SV) }\end{array}$} & $\begin{array}{c}\text { Degrees } \\
\text { of } \\
\text { Freedom } \\
\text { (D.F.) }\end{array}$ & Sum of Squares (S.S) & $\begin{array}{c}\text { Mean Sum of } \\
\text { Squares (MSS) }\end{array}$ & $\begin{array}{l}\text { Expected Mean } \\
\text { Sum of Squares } \\
\text { (EMSS) }\end{array}$ \\
\hline $\begin{array}{l}\text { Plots/Treatment } \\
\text { Levels A) }\end{array}$ & (p-1) & $n q \sum_{i}\left(\overline{y_{i . .}}-\overline{y_{\ldots}}\right)^{2}=S_{p}^{2}$ & $\frac{S_{p}^{2}}{(p-1)}=T$ & $\sigma_{n}^{2}+n \sigma_{q}^{2}+n q \sigma_{r}^{2}$ \\
\hline $\begin{array}{l}\text { Plants/Plot(Level } \\
\text { B within A) }\end{array}$ & $\mathrm{p}(\mathrm{q}-1)$ & $n \sum_{i} \sum_{j}\left(\overline{y_{i . .}}-\bar{y}\right)=S_{q}^{2}$ & $\frac{S_{q}^{2}}{p(q-1)}=p$ & $\sigma_{n}^{2}+n \sigma_{q}^{2}$ \\
\hline $\begin{array}{l}\text { Fruits/Plant/Plot } \\
\text { Sampling }\end{array}$ & $\mathrm{pq}(\mathrm{n}-1)$ & $\sum_{i} \sum_{j} \sum_{k}\left(y_{i j k}-\bar{y}_{i j}\right)^{2}=S_{n}^{2}$ & $\frac{S_{n}^{2}}{p q(n-1)}=S$ & $\sigma_{n}^{2}$ \\
\hline Total & $\mathrm{pqn}-1$ & $\sum_{i} \sum_{j} \sum_{k}\left(\overline{y_{i j k}}-\bar{y}\right)^{2}$ & & \\
\hline
\end{tabular}

Where, $\mathrm{p}=$ number of plot or treatment, $\mathrm{q}=$ number of plants/plot and, $\mathrm{n}=$ number of fruits/plant/plot. Also $\mathrm{T}=\mathrm{The}$ mean sum of square of Treatment, $\mathrm{P}=$ The mean sum of square of Plant, $S=$ The mean sum of square of Sampling respectively.

According to estimation of optimum sampling plan, Snedecor and Cochran (1967), the variance component may be estimated as.

The components of variance $\sigma_{n}^{2}, \sigma_{q}^{2} a n d \sigma_{p}^{2}$ estimated by

$\hat{\sigma}_{n}^{2}=S, P=\bar{\sigma}_{n}^{2}+n \sigma_{q}^{2}$ and $T=\sigma_{n}^{2}+n \sigma_{q}^{2}+n q \sigma_{p}^{2}$ i.e.

$\hat{\sigma}_{q}^{2}=\frac{P-S}{n}$ and $\hat{\sigma}_{p}^{2}=\frac{T-P}{n q}$

\section{Estimation of optimum sampling plan}

The concept of variance of mean $\left(S_{\bar{y}}^{2}\right)$ was used in driving optimum sampling plan (Patel \& Dalal, 1992).

Thus variance of mean $\left(S^{2} \bar{y}\right)$ is worked out using the relation:

$$
S_{y}^{2}=\frac{\hat{\sigma}_{p}^{2}}{P}+\frac{\hat{\sigma}_{q}^{2}}{p q}+\frac{\hat{\sigma}_{n}^{2}}{n p q}
$$


$\hat{\sigma}_{p}^{2}, \hat{\sigma}_{q}^{2}$ and $\sigma_{q}^{2}$ for the character were obtained from the analysis of variance table.

The same variance of mean can be altered for the mean by using various combinations of $\mathrm{q}$ and $\mathrm{n}$ in equation (2)

$S_{\bar{y}}^{2}=\frac{\hat{\sigma}_{p}^{2}}{p}+\frac{\hat{\sigma}_{q}^{2}}{p q^{\prime}}+\frac{\hat{\sigma}_{n}^{2}}{n^{\prime} q^{\prime} p}$

where $\mathrm{q}^{\prime}$ and $\mathrm{n}^{\prime}$ are the altered values of $\mathrm{q}$ and $\mathrm{n}$ respectively.

The component $\hat{\sigma}_{p}^{2}$ was assumed as constant, as it represented variation due to treatments.

Efficiency of new sampling plan,

$$
E=\frac{S_{\bar{y}}^{2}}{S_{\bar{y}}^{\prime 2}}
$$

The formula of saving the work/time load i.e time factor (TF) without sacrificing precision as compared with original plan i.e 30 fruits (3plant/plot $\mathrm{x}$ 10fruits/plant) per plot is defined as

$T F(\%)=\frac{q^{\prime} n^{\prime}-q n}{q^{\prime} n^{\prime}} \times 100$

where, $\mathrm{q}^{\prime}=3, \mathrm{n}^{\prime}=15, \mathrm{q}=1,2,------, 3$ and $\mathrm{n}=1,2,-------, 10$. In this experiment, 30 fruits per plot is considered as the control or original plan.

\section{Results and Discussion}

In search of alternative sampling plan, a total of 45 sampling plants per plot have been investigated for the value of $\mathrm{q}$ from 1 to 3 plant per plot and from 1 to 15 fruits per plant. The estimated variance components under two-way classification model of equation 1 are shown in the Table 2 .

Table 2. The estimated variance components for plots $\left(\hat{\sigma}_{p}^{2}\right)$, plants $\left(\hat{\sigma}_{q}^{2}\right)$ and

\begin{tabular}{lccc}
\multicolumn{2}{c}{ fruits $\left(\hat{\sigma}_{n}^{2}\right)$} & & \\
\hline Variance component & Fruit Length & Fruit Breadth & Fruit Weight \\
\hline$\hat{\sigma}_{p}^{2}$ & 0.12 & 2.58 & 2.07 \\
$\hat{\sigma}_{q}^{2}$ & 0.03 & 0.25 & 0.17 \\
$\hat{\sigma}_{n}^{2}$ & 25.97 & 276.18 & 183.37 \\
\hline
\end{tabular}


The relative efficiency of each plants both for original plan ( 3 plants per plot and 10 fruits per plants). Using equation-4 the relative efficiency of new alternate sampling plans is given in Table-3. The computed relative efficiency and TF (\%) are given in the Table 3.

The other alternate plan with 3 plant per plot and 9 fruits per plant (total 27 fruits per plot) had also 98.80 percent efficiency in comparison to original plan but had 10 percent less amount field work (Using equation 5). The other plan which can be employed with same efficiency is to select 3 plants at random per plot and measure 8 fruits each selected plant ( 24 fruits per plot) had 97.47 but work load will be about 20 percent less than the plan with 3 plants $x 10$ fruits per plot.

The results revealed that work load for field operation like lagging of flowers, harvesting and measurement of individual fruit could be reduced effectively without sacrificing efficiency by selecting proper sampling plan.

Table 3. The relative efficiency for some of the alternative sampling plants

\begin{tabular}{|c|c|c|c|c|c|c|}
\hline \multicolumn{2}{|c|}{ Number of } & \multirow[b]{2}{*}{$\begin{array}{l}\text { Fruit Length } \\
\quad(\mathrm{cm})\end{array}$} & \multirow[b]{2}{*}{$\begin{array}{c}\text { Fruit Breadth } \\
(\mathrm{cm})\end{array}$} & \multirow{2}{*}{$\begin{array}{c}\text { Fruit } \\
\text { Weight } \\
(\mathrm{cm})\end{array}$} & \multirow[b]{2}{*}{$\begin{array}{c}\text { Average } \\
\text { over traits }\end{array}$} & \multirow[b]{2}{*}{$\begin{array}{c}\text { Work/Time } \\
\text { load }(\%)\end{array}$} \\
\hline $\begin{array}{l}\text { Plants } \\
\text { per plot }\end{array}$ & $\begin{array}{c}\text { Fruits per } \\
\text { plant }\end{array}$ & & & & & \\
\hline 1 & 12 & 35.82 & 40.45 & 38.46 & 38.24 & 60 \\
\hline 1 & 13 & 35.99 & 40.60 & 38.60 & 38.40 & 57 \\
\hline 1 & 14 & 36.13 & 40.73 & 38.73 & 38.53 & 53 \\
\hline 1 & 15 & 36.26 & 40.85 & 38.83 & 38.65 & 50 \\
\hline 2 & 10 & 67.99 & 72.78 & 70.47 & 70.41 & 33 \\
\hline 2 & 11 & 68.41 & 73.13 & 70.81 & 70.78 & 27 \\
\hline 2 & 12 & 68.77 & 73.42 & 71.10 & 71.11 & 20 \\
\hline 2 & 13 & 69.07 & 73.67 & 71.34 & 71.36 & 13 \\
\hline 2 & 14 & 69.34 & 73.88 & 71.56 & 71.59 & 7 \\
\hline 2 & 15 & 69.57 & 74.07 & 71.74 & 71.79 & 0 \\
\hline 3 & 7 & 95.40 & 98.00 & 96.31 & 96.57 & 30 \\
\hline 3 & 8 & 96.51 & 98.82 & 97.14 & 97.47 & 20 \\
\hline 3 & 9 & 98.38 & 99.77 & 98.20 & 98.80 & 10 \\
\hline 3 & 10 & 100 & 100 & 100 & 100 & $\mathbf{0}$ \\
\hline 3 & 11 & 98.68 & 100 & 98.78 & 99.29 & 10 \\
\hline 3 & 12 & 99.18 & 100.43 & 99.15 & 99.71 & 20 \\
\hline 3 & 13 & 99.60 & 101.11 & 99.47 & 100.06 & 30 \\
\hline 3 & 14 & 99.97 & 101.37 & 99.74 & 100.36 & 40 \\
\hline 3 & 15 & 100.29 & 101.61 & 99.98 & 100.59 & 50 \\
\hline
\end{tabular}




\section{Conclusion}

To search the optimum sampling plan for yield contributing characters of pointed gourd, we have been selected a two-way analysis of variance model in this research. According to this objective and research question various variance components on the selected attributes of the plant and together with the relative efficiency has been computed.

Among different sampling plans a plan of 3 plants per plot and 7 fruits (total 21 fruits per plot) are found to be on an average 96.57 percent efficient in compared with original sampling plan of 3 plants/plot and 10 fruits per plant (30 fruits per plot). By adopting this new plan 30 percent work load (time) could be saved without compromising with its precision.

\section{References}

Federer, W. T. 1963. Experimental design. Theory and application, Oxford and IBH Publishing Co. New Delhi, India.

Hossain,M.I., M.S. Islam, M.A. Hossain, S.Nasrin, and S.Yesmin. 2005. Determination of optimum sampling plant characters of brinjal. International J. Sustainable Agril. Technol. 1(6): 25-29.

Hossain,M.I.,Muhammad Shuaib, Kabita, Muhammad Tareq, M.S. Kabir and M. A. Uddin. 2008. Optimum sampling for measuring different plant characters of Teasle gourd. Eco-friendly Agril. J. 1(3): 172-175.

Islam, M.S., N. Mohammad, K.S. Rahman, M.M. Rahman and A.K.M.A. Hoque. 2013. Optimum sampling for measuring different plant characters of bitter gourd. Ecofriendly Agril. J. 6(11): 234-237.

Islam, M.S., N. Mohammad, K.S. Rahman, M.M. Rahman and A.K.M.A. Hoque. 2012. A study of optimum sampling for measuring different plant characters of sweet gourd. J. Bangladesh Soc. Agril. Sic. Technol. 9(1 \&2):195-199.

Islam, M.S., K. Sen and K. Rahim. 2000. Estimation of optimum sample size and number of replications in RCBD with unequal observation per cell. Dhaka University J. Sci. 48(1): 89-94.

Islam, M. S. 2001. Statistical development of field plot technique for agronomic experiments. Unpublished Ph. D. thesis, Dhaka University, Dhaka, Bangladesh.

Kempthorne, O. 1952. Design and analysis of experiment, John Wiley and Sons, Inc, New York, USA.

Mohammad, N., M.S. Islam, K.S. Rahman, M. M. Rahman and S. Nasrin. 2015. Determination of optimum sample for measuring the contributing characters of bottle gourd. Bangladesh J. Agril. Res. 40(4): 703-709.

Patel, J.N. and K.C. Dalal. 1992. Sampling technique for measuring pod characters of okra. Gujarat Agricultural University Research Journal. 18(1): 81-84.

Rigney, J.A. and WI L. Nelson. 1951. Some factors affecting the accuracy of sampling cotton for fibre determinations. Agronomy J. 43: 531-535.

Snedecor, G.W and W.G. Cochran. 1967. Statistical Methods. Sixteen Edition, The Iowa State University Press, Ames, Iowa, USA. 
